\title{
Radiation-Induced Reciprocal Translocations in Safflower (Carthamus tinctorius L.)
}

\author{
Rakesh Chandra Verma* and Pratibha Shrivastava \\ School of Studies in Botany, Vikram University, Ujjain (M.P.) 456010, India \\ Received May 14, 2014; accepted August 10, 2014
}

\begin{abstract}
Summary Seeds of Carthamus tinctorius L. $(2 n=24)$, an oil yielding plant, were treated with different doses $(5,10,15,20,25 \mathrm{kR})$ of gamma rays. Three translocation heterozygotes were observed at meiotic division for $10-$ and $25-\mathrm{kR}$ doses. The induced translocation heterozygotes showed a ring or chain of four chromosomes in most of the cells at diakinesis/metaphase I. The induced mutants showed unequal distribution at anaphase I, reduced vigour, delayed flowering, low flower number, low pollen fertility, and low seed sets as compared to control plants. Induction of permanent chromosomal structural changes may also sometime bring out favorable morphological variation. It is expected that the mutant, when established, could be used in further cytological and breeding programs.
\end{abstract}

Key words Safflower, Reciprocal translocation, Gamma ray, Heterozygote, Mutation.

Safflower (Carthamus tinctorius) belongs to the family Asteraceae, and is an important crop in the traditional farming of the semi-arid areas of India and other Mediterranean countries (Oad et al. 2002, Tuncturk and Ciftici 2004). Safflower is an annual plant and used as oil and forage crop. This oil seed crop shows great promise as oil, meal birdseed and good economic returns with minimal irrigation. Safflower gives more response and yield and a high economic result because of its greater tolerance to drought, oil content and composition and other oil characteristics (Kumar 2000). The oil contains polysaturated fatty acids that are good for a healthy heart. Safflower oil is thought to be one of the highest quality vegetable oils, containing oleic acid and linoleic acid (Fernández-Martínez et al. 1993).

Genetic variation is very important for crop breeding programs. Mutation is a valuable tool to create novel traits for living organisms and can be classified as natural and induced mutations. Natural mutations are still occurring in the crop and its wild relatives, though at a low rate, and the resulting beneficial characters can be selected for human needs. Mutagenic agents, such as physical and chemical mutagens are used to either increase mutation rates or yield mutants unavailable from natural sources. Induced mutagenesis is an efficient method for induction of morphological and genetic variabilities in plants.

The application of radiations as a mutagen is of great importance not only to analyse any gene functions through novel mutant isolation, but also to improve global food situations by providing new crop varieties with beneficial traits (Magori et al. 2010). The present study was aimed to induce mutations with the help of gamma radiations which produced three translocation heterozygotes whose behavior during meiosis has been presented here.

\footnotetext{
*Corresponding author, e-mail: rakeshcverma@yahoo.com

DOI: $10.1508 /$ cytologia.79.541
} 


\section{Materials and methods}

Certified and healthy seeds of Carthamus tinctorius used in the present study were procured from the Krishi Vigyan Kendra, Ujjain. Dry seeds were irradiated with different doses (5, 10, 15, 20 and $25 \mathrm{kR}$ ) of gamma rays at the Bhabha Atomic Research Center in Mumbai. The control and irradiated seeds of each dose were sown in separate pots.

For meiotic analysis, young flower buds were collected in the early morning and fixed in $1: 3$ (acetic acid:absolute alcohol) mixture for at least $24 \mathrm{~h}$. The slides were prepared by squashing the anthers in $2 \%$ iron acetocarmine. Photomicrographs were taken from temporary slides under oil immersion $(\times 100)$ and magnified to $\times 1000$ using the Leica Photographic microscope.

\section{Results}

Control plants revealed 12 bivalents $(2 n=24)$ at diakinesis/metaphase I (Table 2, Fig. 1a, b), of which on average 9-10 were ring while 2-3 were rods (Fig. 1a). Mean chiasma frequency per cell was 22.42 with a terminalization coefficient of 0.83 (Table 3 ). The chromosomes showed equal distribution of $12: 12$ at anaphase I.

Three gamma radiation induced translocation heterozygotes were identified at meiotic division in $\mathrm{M} 1$ generation of irradiated diploid plants designated as $\mathrm{CT}_{1}, \mathrm{CT}_{2}$ and $\mathrm{CT}_{3}$. The $\mathrm{CT}_{1}$ plant was obtained from $10 \mathrm{kR}$ and two plants $\left(\mathrm{CT}_{2}\right.$ and $\left.\mathrm{CT}_{3}\right)$ were from $25 \mathrm{kR}$ of radiation doses (Table 1). These three translocation heterozygotes were characterised by the presence of ring or chain of four chromosomes at metaphase I (Fig. 1d-i). Beside this, other associations were also found like univalents along with bivalents in various frequencies.

In $\mathrm{CT}_{1}, 50 \mathrm{PMCs}$ were analysed at diakinesis/metaphase I, of which $82 \%$ of the cells were found with the presence of ring/chain of four chromosomes along with 10 bivalents (Table 1). Rings of four chromosomes were found in 35 cells and chains of the four were found in only six cells (Table 2). Chiasma frequency was 19.20 per cell (Table 3). Eleven bivalents and two univalents were also found in $8 \%$ of the PMCs (Table 1). Anaphase I was irregular with an unequal distribution of $11: 13$ in $25 \%$ of the cells. Pollen stainability was $35 \%$ and there were about $70 \%$ sterile seeds.

Table 1. Gamma ray treatment and percentage of the different types of associations at diakinesis and metaphase I in translocation heterozygotes.

\begin{tabular}{|c|c|c|c|c|c|c|}
\hline \multirow{2}{*}{$\begin{array}{l}\text { Translocation } \\
\text { heterozygotes }\end{array}$} & \multirow{2}{*}{ Mutagen } & \multirow{2}{*}{$\begin{array}{c}\text { No. of cells } \\
\text { analysed }\end{array}$} & \multicolumn{4}{|c|}{ Types of associations (\%) } \\
\hline & & & $1 \mathrm{IV}+10 \mathrm{II}$ & $2 \mathrm{IV}+8 \mathrm{II}$ & $12 \mathrm{II}$ & $11 \mathrm{II}+2 \mathrm{I}$ \\
\hline $\mathrm{CT}_{1}$ & $10 \mathrm{kR}$ & 50 & 82 & - & 10 & 08 \\
\hline $\mathrm{CT}_{2}$ & $25 \mathrm{kR}$ & 50 & 92 & - & 06 & 02 \\
\hline $\mathrm{CT}_{3}$ & $25 \mathrm{kR}$ & 50 & 78 & 10 & 12 & - \\
\hline
\end{tabular}

Table 2. Frequency of ring and chain of four chromosomes in three induced translocation heterozygotes.

\begin{tabular}{|c|c|c|c|c|c|c|c|c|c|}
\hline \multirow{3}{*}{ Genotypes } & \multirow{3}{*}{$\begin{array}{l}\text { No. of cells } \\
\text { analysed }\end{array}$} & \multicolumn{8}{|c|}{ Diakinesis/Metaphase I } \\
\hline & & \multicolumn{2}{|c|}{ Ring of four } & \multicolumn{2}{|c|}{ Chain of four } & \multicolumn{3}{|c|}{ Ring + chain of four } & \multirow{2}{*}{$\frac{\text { No. of bivalents }}{\text { Mean }}$} \\
\hline & & No. & Mean & No. & Mean & No. & Mean & $\%$ & \\
\hline Control & 50 & - & - & - & - & - & - & - & 12 \\
\hline $\mathrm{CT}_{1}$ & 50 & 35 & 0.7 & 06 & 0.12 & 41 & 0.82 & 82 & 10.28 \\
\hline $\mathrm{CT}_{2}$ & 50 & 42 & 0.84 & 04 & 0.08 & 46 & 0.92 & 92 & 10.14 \\
\hline $\mathrm{CT}_{3}$ & 50 & 26 & 0.52 & 13 & 0.26 & 39 & 0.78 & 78 & 10.04 \\
\hline
\end{tabular}


Table 3. Chiasma frequency, range and terminalization coefficient in control and translocation heterozygotes.

\begin{tabular}{lcccccc}
\hline \hline Plants & $\begin{array}{c}\text { No. of cells } \\
\text { analysed }\end{array}$ & $\begin{array}{c}\text { Chiasma } \\
\text { frequency/cell }\end{array}$ & Range & $\begin{array}{c}\text { Chiasma } \\
\text { terminalized }\end{array}$ & $\begin{array}{c}\text { Chiasma } \\
\text { unterminalized }\end{array}$ & $\begin{array}{c}\text { Terminalization } \\
\text { coefficient }\end{array}$ \\
\hline Control & 50 & 22.42 & $20-25$ & 18.72 & 3.72 & 0.83 \\
$\mathrm{CT}_{1}$ & 50 & 19.20 & $19-22$ & 17.80 & 1.40 & 0.92 \\
$\mathrm{CT}_{2}$ & 50 & 20.32 & $22-23$ & 18.60 & 1.72 & 0.91 \\
$\mathrm{CT}_{3}$ & 50 & 21.60 & $18-21$ & 15.42 & 6.18 & 0.71 \\
\hline
\end{tabular}


Figs. 1a-i. Meiotic stages in control and translocation heterozygotes. a-c. Diakinesis/metaphase I in control; note- 12 II. d-i. Diakinesis/metaphase I of translocation heterozygotes. d. Diakinesis. e-g. Ring of 4 chromosomes+10II. h. Chain of 4 chromosomes+10II. i. Ring of 4 chromosomes $+10 \mathrm{II}$ at metaphase plate.

In $\mathrm{CT}_{2}$ and $\mathrm{CT}_{3}$, both were also identified at meiotic division by the presence of ring/chain of four chromosomes along with 10 bivalents in $92 \%\left(\mathrm{CT}_{2}\right)$ and $78 \%\left(\mathrm{CT}_{3}\right)$ of 50 PMCs analysed at diakinesis/metaphase I (Table 1). Rings of four chromosomes were found in 42 cells and chains of the four were found in only four cells in $\mathrm{CT}_{2}$; rings of the four were found in 26 cells and chains of the four were found in only 13 cells in $\mathrm{CT}_{3}$ (Table 2). Anaphase I was regular with laggards found occasionally in $\mathrm{CT}_{3}$. Chiasma frequency was $20.32\left(\mathrm{CT}_{2}\right)$ and $21.60\left(\mathrm{CT}_{3}\right)$ per cell (Table 3). Pollen 
stainability was $30 \%\left(\mathrm{CT}_{2}\right)$ and $25 \%\left(\mathrm{CT}_{3}\right)$, and there were about $85 \%$ sterile seeds in both the translocation heterozygotes.

\section{Discussion}

In the present study, three induced reciprocal translocation heterozygotes of safflower $(C$. tinctorius) were isolated from gamma-irradiated (5, 10, 15, 20 and $25 \mathrm{kR}$ ) seeds which may be useful for further cytogenetic and molecular studies. Such gamma ray-induced translocation heterozygotes have been reported earlier in Pisum (Müller 1976), Vicia faba (Verma and Rao 1994), Phlox drummondii (Verma and Sharma 2000) and in safflower (Srivastava and Kumar 2011). Based on the present observations, cells of these induced translocation heterozygotes show mutual exchange of chromosome segments between two non-homologous chromosomes pairs. The four chromosomes appear as a cross because of partial pairing in pachytene, and the possible diakinesis to metaphase I configurations depended upon chiasmata formation (Ashraf and Bassett 1986).

The translocation heterozygotes were identified by the presence of a ring or chain of four chromosomes at diakinesis/metaphase-I. In all three heterozygotes $\left(\mathrm{CT}_{1}, \mathrm{CT}_{2}\right.$, and $\left.\mathrm{CT}_{3}\right)$, the number of ring quadrivalents was more than that of the chain quadrivalents. Predominant presence of ring of four chromosomes suggested adjacent orientation of chromosomes towards one pole, as observed in other plants (Verma and Raina 1990). Perhaps one of the metacentric chromosome pair and one of the other metacentric or submetacentric pair were included in the reciprocal exchange of chromosomes. The presence of metacentric chromosomes in reciprocal translocation was evident from the bigger size of the interchange complex (Verma and Goyal 2012). The chromosome orientation of quadrivalents in translocation heterozygotes at metaphase I is critical. According to Zaman and Rai (1972), if the sites of breaks are closer to the centromeres and the interchange pieces more or less equal in length, a high frequency of ring interchange complexes is observed. If one of the exchanged pieces is relatively long and the other is short, more chain interchange complexes are expected. Kaul (1977) observed in Allium cepa that the exchanged chromosomal pieces were relatively short and therefore chain interchange complexes were formed. Also in the event of a failure of chiasma to form in one of the four arms or of early terminalization of a chiasma in one arm, an open chain of four chromosomes would result.

The association of chromosomes in ring and chain of four chromosomes, as well as the presence of the bivalent and univalents, have suggested a double interchange involving two nonhomologous chromosomes (Srivastava and Kumar 2011). The univalent is either a chromosome which altogether failed to pair at zygotene or one which paired to form a bivalent but whose two component chromosomes separated at diplotene because of the absence of chaisma formation between them, or else it is due to precocious anaphasic separation of bivalent (Sarbhoy 1977). In $\mathrm{CT}_{2}$, some PMCs showed open types of configurations that suggested the involvement of a sufficient length of the pairing segments, and in $\mathrm{CT}_{3}$, few PMCs showed closed configurations which may be the result of short pairing segments (Müller 1976).

Alternate I and II segregation give rise to fertile gametes while adjacent I and II give rise to nonviable duplication and deficiency gametes. When these two types of segregations are of equal frequency, the result is semisterility (Endrizzi 1974). Kaul (1977) has also suggested that the gametic lethality in a translocation heterozygote is dependent upon the distribution of the four chromosomes in a ring or a chain configuration at anaphase I. The chromosome distribution is determined by the centromere orientation that may be either concordant or discordant. The negative genetic effect of mutagens on pollen fertility may be due to cumulative effects of various meiotic aberrations as mentioned by Burnham (1962). As is known, this would produce unbalanced types of gametes, and this was reflected in the present case by high sterility exhibited by all three plants. 


\section{References}

Ashraf, M. and Bassett, M. J. 1986. Cytogenetic analysis of translocation heterozygosity in the common bean (Phaseolus vulgaris L.). Can. J. Genet. Cytol. 28: 574-580.

Burnham, C. R. 1962. Discussions in Cytogenetics. Burgess Publishing Company, Minneapolis.

Endrizzi, J. E. 1974. Alternate-1 and Alternate-2 disjunctions in heterozygous reciprocal translocations. Genetics 77: 5560.

Fernández-Martínez, J., Rio, M. D. and Haro, A. D. 1993. Survey of safflower (Carthamus tinctorius L.) germplasm for variants in fatty acid composition and other seed characters. Euphytica 69: 115-122.

Kaul, M. L. H. 1977. Cytogenetics of white Allium I. Translocation heterozygosity. Cytologia 42: 681-689.

Kumar, H. 2000. Development potential of safflower in comparison to sunflower. Sesame and Safflower Newsletter 15: 86-89.

Magori, S., Tanaka, A. and Kawaguchi, M. 2010. Physically Induced Mutation: Ion Beam Mutagenesis. In: Meksem, K. and Khal, G. (eds.). The Handbook of Plant Mutation Screening. Wiley-VCH, Weinheim. pp. 3-16.

Müller, D. 1976. Microsporogenesis and seed production of different reciprocal translocations of Pisum. Egypt. J. Genet. Cytol. 5: 207-219.

Oad, F. C., Samo, M. A., Qayyum S. M. and Oad, N. L. 2002. Inter and intra row spacing effect on the growth, seed yield and oil content of safflower. Asian J. Plant Sci. 1: 18-19.

Sarbhoy, R. K. 1977. Cytogenetical studies in the genus Phaseolus Linn. III. Evolution in the genus Phaseolus. Cytologia 42: 401-413.

Srivastava, P. and Kumar, G. 2011. Gamma ray induced chromosomal interchange in safflower (Carthamus tinctorius L.). Cytologia 76: 237-241.

Tuncturk, M. and Ciftici, V. 2004. Relationships among traits using correlation and path coefficient analysis in safflower (Carthamus tinctorius L.) shown different fertilization levels and row spacing. Asian J. Plant Sci. 3: 683-686.

Verma, R. C. and Goyal, S. 2012. Induced reciprocal translocation in Pisum sativum L. Cytologia 77: 485-489.

Verma, R. C. and Raina, S. N. 1990. Cytogenetics of Crotalaria IV Induced translocation lines in C. juncia. Nucleus 33: 11-14.

Verma, R. C. and Rao, A. N. 1994. Radiation induced inversion and translocations in Vicia faba. J. Cytol. Genet. 29: 5963.

Verma, R. C. and Sharma, R. 2000. Radiation induced cytological changes in Phlox drummondii. J. Cytol. Genet. 1: 33-39.

Zaman, M. A. and Rai, K. S. 1972. Cytogenetics of thirteen reciprocal translocations in Collinsia heterophylla. Cytologia 37: 629-638. 